\title{
英語名詞の多義性解消における文脈としての場面情報の評価
}

\begin{abstract}
角田 達彦 ${ }^{\dagger}$ 田中 英彦卉
本論文では，意味解析を主とする自然言語処理システムにおける語の意味の曖昧性解 消の処理の効率化を場面に基づく文脈情報を利用して実現する方法を提案する．現在 における文脈依存の意味処理では文脈の定義方法と知識の獲得方法が問題とされる. また実装時には意味選択の組合せ爆発による計算量の大きさが問題となる．文脈情報 により一部の語に対してでも語義の優先順位づけが有意に行なわれれば，共起関係な どを用いて他の語の多義性や構文解析の解空間を早く絞り込むことができる。本論文 では, 談話内の言語外知識である場面情報を空間的連想による文脈情報と位置付け, 画像理解による知識獲得の近似として視覚辞書を利用し, 実際の物語文を対象にし評 価した結果を示す．場面に関連する各英語名詞に対し独立に平均 1.5 倍以上の処理速 度向上が得られている。また多義性解消率は全く情報がない場合の $51 \%$ に比べ本手 法では $83 \%$ まで上昇する．あわせて場面情報の知識表現の違いによる効果の違いに ついての考察, 手法の限界点, およびシステムに加えて必要とされる場面解析機構に ついての考察を述べる.
\end{abstract}

キーワード：文脈, 多義性解消, 場面, 辞書, 連想, 優先度

\section{Evaluation of Scene Information as Context for English Noun Disambiguation}

\author{
TATsuhiko Tsunoda ${ }^{\dagger}$ and Hidehiko TANAKa ${ }^{\dagger \dagger}$
}

\begin{abstract}
We propose an efficient method to disambiguate English nouns using scene information as context. Recent research directions into context dependent analysis point out the difficulty of defining context and acquiring knowledge. Another problem is the efficiency of resolving semantic constraints. To resolve these problems, we use knowledge from a pictorial dictionary available on the market. It provides spatialscene information as extra-lingual knowledge required for discourse analysis. One of its targets is to disambiguate words. We compared our method with random search approach on a narrative story. The experimental analysis supports that the worddisambiguating speed with our method is over 1.5 times faster than that with the random search. Also it indicates that the disambiguating rate with our method is $83 \%$, higher than that with the random search $(51 \%)$. We discuss the importance of the representational type for the scene information, evaluate our method's limits, and argue future technologies required to analyze the spatial-scene.
\end{abstract}

KeyWords: Context, Disambiguation, Scene, Dictionary, Association, Priority

†京都大学 工学研究科 電子通信工学, Department of Electronics and Communication, Kyoto University †† 東京大学 工学部 電気工学科, Department of Electorical Engineering, University of Tokyo 


\section{1 まえがき}

文の意味を効率よく適切に理解するためには語義の暧昧性を文脈によって早期に絞り込むこ とが必要である。通常のボトムアップな手法による意味・構文解析方法では解の探索空間の広 がりにより処理の爆発の問題が生じる。また局所的制約のみでは解を絞り切れず，誤った解を 出力する問題もある.

例としてしばしば引用される次の文 (Waltz and Pollack 1985) について考えてみる.

'John shot some bucks.'

shot と bucks の品詞および意味の曖昧性が各々数十通りあるため, 数百通りの意味の組合せが あるとされている。しかし, Hunting (狩猟) や Gamble (ギャンブル)などの文脈が与えられる とそれぞれ即座に意味が求まり，前者では「ジョンは牡鹿を銃で撃った.」という解釈がなされ， また後者では「ジョンは何ドルか賭けてすってしまった.」という解釈がなされる. 文脈情報が ないと効率的に解が得られないばかりか, 正しい意味に収束さえしない可能性が大きい.

近年この文脈依存性に関する二つの問題を解決するため，談話中の前後の脈絡としての一貫 性，すなわち文脈を形成する知識の重要性が着目されつつある。それは文の表層から得られる 文法的知識などの言語内知識, および一般常識や世界知識などの言語外知識に分けることがで きる。また意味が談話内の状況により制約を受けるか，発話された環境により制約を受けるか によって文脈情報を分けることもできる，たとえば，「昨日東京で雨が降った.」という発話がな されたとする．前者の「談話内の状況」は言及されている状況すなわち「昨日東京で」を指して いる.しかし，この発話が正直者によってなされたか，実際にはいつどこでなされたのか，緊 急事態の発生の説明なのかなど，発話された時点の外界の状況が問題になる場合もある，この ような「発話された環境による制約」は談話内の状況に加わり作用するもので重要ではあるも のの, 今後研究される部分としここでは扱わないという立場をとる. 本研究ではテキストに絞 り, 特に物語を解釈する場合に限り, 外界の状況によらない談話内の言語外知識による文脈情 報の，曖昧性解消の処理効率への効果について絞り議論を行なう.

言語外の知識に基づく文脈情報に依存したテキスト解釈の手法はいくつか提案されている. それらは知識の表現とそれにともなう処理方法の違いによって, 文脈を記号的な知識として明 示的に与える方法と, ネットワーク上の活性伝搬に基づくパターン的相互作用により文脈を非 明示的に表現し曖昧性解消を効率的に実現する方法とに大きく分けることができる.

前者の代表例としては，物語の一般的構成を文法規則として表す物語文法 (Rumelhart 1975) や, Schank らの文脈理解の研究 (Schank and Abelson 1977; Schank and Riesbeck 1981; Schank 1982) などがあげられる. 特に Schank らは動詞を中心とした概念依存構造によって意味を表 現し，文脈として場面に関する知識を予め持つスクリプトや，意困・目的と行動に関する知識 としてのゴールとプラン, そして知識構造を抽象化し階層化して効率良く持つ MOPs などの重 
要性を論じている。

また後者に関しては文ごとにネットワークを組み活性伝搬させる方法 (Waltz and Pollack 1985; 田村・安西 1987), 曖昧性を要素の意味内容や要素間の関係に内在させ表現上の組合せ爆 発を抑える方法 (Hirst 1988; 奥村・田中 1989; 小嶋・古郡 1991), 連想記憶による解の絞り込 みと記号処理に基づく矛盾検出による曖昧性解消の効率化 (Tsunoda and Tanaka 1993) などが 手法としてあげられる。

これらの研究の問題点は, 実際に知識を何から獲得し与えるかが不明確であること, 実際の テキストにおける評価や問題点に対する考察がなされていないこと，そして他の手法との組合 せに対する問題点，限界点が未整理であることである。

これに対し，コーパスを利用し，多義性のある単語の周辺語の統計情報からシソーラス上の カテゴリの Bayes 確率を求め, 意味を決定する方法 (Yarowsky 1992) がある.この研究では百 科事典の中から知識を獲得し，百科事典の文中の単語に対する評価を行なっているが，一般の さまざま種類のテキストに対してどの程度有用であるかは調査の余地がある。またトピック の入れ子の問題などの言語の複雑な事象に対応するためには, 言語現象に応じて知識を分類し, 適切な知識源を明らかにすることと，このような統計的手法を同時に研究することは意味があ ると思われる。したがって現在必要なことは，処理する知識の性質を想定した細分化，および それぞれの知識を用いた際の実際の文に対する効果の調査である。

本論文では談話内の言語外知識をさらに連想処理の観点から分類し，その一部として場面知 識を視覚辞書から構成し利用した場合の多義性解消の効率化に対する効果の評価および検討を 行なう。視党辞書は物の名前を, 出てくる場面や対象物の形から引くことを目的に出版されてい る辞書である．日常生活に出てくる場面を網羅的に絵に描き，その中に登場する物の名前を対応 づけて欄外に列挙してある．視覚辞書は数冊出版されているが，ここでは OXFORD-DUDEN の Pictorial English Dictionary を用いる. 多義性解消機構の実装に際しては構文解析と意味解 析は通常の記号処理手法を用いることを想定する．その中の意味辞書から語義を取り出す順番 を決める方法の一つを提案する，場面を一つに固定した場合にそのような情報を使わない場合 に比べ，正しい解にたどり着くまでの語義の検索回数 (試行回数と定義する) がどの程度減少す るかを物語文にて評価する.すなわち，各単語に意味が複数あったり，とりうる構文木が複数 ある場合には，そのすべての組合せの数だけの解が候補となりうる．これらの組合せから解が 一つずつ生成され，すべての制約条件を満たすかどうかが検証される。このため構文的曖昧性 も考慮する必要があるが，他の方法あるいは本手法と他の方法を組み合わせることによって解 決するものとして考え，ここでは陽には扱わないこととする。ここでは語の意味の選択の部分 のみに着目し, 一つの単語の複数の意味の中で, 人間が正解と判断する解を出力するまでに検 索された語義の数をここでの試行回数と定義する. 実際の機械翻訳などのシステムでは, 他に 解を制約する知識によってシステム内部で検証を行なう場合に，前処理として尤もらしい語義 
を優先づけして出力するモジュールを目的としている．通常のパーザでは文脈情報が何もない 場合には，各単語の意味はランダムに，あるいは静的に割り当てられている順番で辞書からと り出され検証される。これに対し，場面情報があれば，この取り出しの仕方を変え，場面の中 でありそうな意味を先に取り出し，全体の処理の効率化をはかることができる．多義性解消な どで文脈，特に場面情報の効果および問題点について調べた例は見当たらないようである。こ こでは背景としての役割の部分に絞った場面の知識の構成方法を提案し, 実験と考察を行なう. 上のような語義検索の試行回数を減少させるということに対し，場面情報がどの位有効である かを, 物語文「赤毛のアン」の英語原作の中の台所の場面の中から抽出した単語に対して評価 な行なう。

以下，2.では視覚辞書とシソーラスによる場面情報の構築方法について，3. では場面情報 を利用した多義語の優先順位づけの方法について，また4.では例題にて試行回数の計算方法を 示した後に実文中の単語にて有効性の評価を行なう。 5 .では成功例，失敗例の原因についての 考察を行なう。

\section{2 文脈としての場面情報の構築}

\section{1 文脈情報の分類}

言語外知識に基づく文脈は，(1) 発話のおかれた状況，(2) 領域知識，(3) 注意状態，(4) 発話 者の信念・心的状態，の 4 つに大きく分類することができる (片桐 1989). このうち (2)の領域 知識は, 一般的常識から特定専門分野に属するものまで幅広い知識を指し, 言葉で語られる内容 に関する何らかの知識である，前章での例題 'John shot some bucks.'では，狩猟の場面では牡 鹿が登場することが多いこと，動物を撃つことが普通であることなど，またギャンブルの場面 ではお金を賭けること，儲けたり損をしてみたりすることがあることなど，領域知識の一般的 常識を用いて，ほとんど瞬間的に多義性を解消していることがわかる，一般の情報伝達はこれ らの知識を共有していることを前提として行なわれるため, 共有知識の部分を省いた簡潔な言 語表現をとることができる。このような言語の効率性 (efficiency) とトレードオフにあるものが 自然言語の持つ曖昧性 (ambiguity) であり，同音異義性 (homonymy) や多義性 (polysemy) とし てテキスト表層に現れる (小嶋・古郡 1991)，他にも，言語を効率的に伝達する手段として省略 (ellipsis) や照応 (anaphora) もあげられるが, 一方で受け手がこれらの久落した情報を補うこと が必要であることが問題になる．話者や著者が伝達しようとした正しい意味を復元するために は，適切な知識と処理方法をあわせて見つける必要がある.ささにこのような処理を機械に実 装する場合には，知識の入手のしやすさや処理の効率性も重視しなくてはならない。これらの 要請を満たすものを見い出すためには，自然言語は人間の用いるコミュニケーションの道具な ので，まずは人間の行なっている処理や知識に着目するのが良い方法の一つであると思われる. 
ここでは多義性解消に絞り，処理を次の二つに分けることを考える (Tsunoda and Tanaka 1993).

- 意味の決定のための制約処理 (constraint processing)

- 処理の効率化のための選好処理 (preference processing)

前者は構文解析や格 (意味) の整合性などの評価部であり, 矛盾が発生すると処理がバックト ラックする，後者は過去の記憶に基づき連想処理を行なって解探索の優先順位づけをし，処理 を効率化する．本研究では文脈によって後者の選好処理を行なう方法を考える．

ある文脈に固定したとき，過去の記憶に基づく連想処理はデータの性質によって (1) 空間的 連想 (spatial), (2) 時間的連想 (temporal), (3) 類似 (similar), (4) 反対 (contrary), に分ける ことができる (T. コホネン 1993). 文脈はさらにこれらの関係を組み合わせたものとして考え ることができる (Tsunoda and Tanaka 1993).

この中の (1) の空間的連想に着目してみると，例えばナイフやフォーク，スプーンのように, 人間が一目見て関係があると思われるものもある。それは一緒に扱われることが多いからであ る.しかし，それらに対しては例えば台所の中ではとくに物を食べるための道具として共通の 機能を持っているために, 意味のつながりをより強く主張することができる. 逆に例えば「登 山」や「強盗」,「鉛筆を削る」などの状況ではナイフとフォーク, スプーンどうしの直接の意 味的つながりは薄い。このように, 機能が同じなど, 何らかの状況に応じて意味のつながりを 持って想起される場合に, 空間的連想の特長を積極的に処理に利用することができると思われ る.その共通性をとらえるための土台の一つとして，対象物が現れる背景としての場面をとり あげる。これは Schank らのスクリプト (Schank and Abelson 1977) の Location header にほ ぼ等しく，例えば Restaurant script の Restaurant が対応している. 'John shot some bucks.' の例題では狩猟の場面では 'Hunting'に，そしてギャンブルの場面では‘Gamble(roulette)'に対 応する.「場面」は何らかの行為が行なわれる場や, 何らかの目的が達成される場, あるいは自 然に物が集まる場などに，登場する対象物の集まりを加えることによって定義される，ただし 頑健性を考慮するため, 個々の対象物が現れる必然性を陽に記述することなく, 対象物の集合 によって表現する空間的情報であるとする．したがってここでは他の共起関係や行為による制 約を補完する知識であるという立場をとる。この研究ではそのような場面情報の第一近似とし て OXFORD-DUDEN の辞書 Pictorial English Dictionary を利用しているが, 将来の画像処 理・認識技術の発展による言語処理との統合が実現されれば，より詳細なデータが得られるこ とを仮定する.

さらに(3)の類似の部分を Roget 5th ed. International Thesaurus の上位一下位関係と概念 どうしのまとまりを用いることによって実現し，場面に登録されていない語に対しての頑健性 を実現している。 


\section{2 場面情報源としての Pictorial Dictionary}

前述のように場面情報の第一近似として OXFORD-DUDEN の Pictorial English Dictionary (OPED) を用いる。これは日常生活に出てくる場面を絵に描き，さらに登場する物の名前を対 応づけて欄外に列挙してある辞書であり，もともと物の名前を出てくる場面と対象物の形から 引くのが目的のものであるので，言語では明示的には通常扱われない常識の一部を含んでいる と考えることができる。辞書は Man and his Social Environment などの 11 クラスに大きく分 かれており，さらに Kitchen などの 384 カテゴリに小さく分かれている。このカテゴリごとに 絵が付与されており，この絵を空間的情報としての場面の近似であるとして扱うことにする. 辞書に登録されている単語数は約 27,500 語であり,一つの場面に登録されている単語は重複す る場合も数えて平均約 184 語である。例えば Kitchen の場面の冒頭を列挙してみる.

1 housewife

2 refrigerator (fridge, Am.icebox)

3 regrigerator shelf

4 salad drawer

5 frozen food compartment

この中で主体となる語は被修飾語の名詞である。修飾語の名詞も付随して場面に登場する可 能性が非常に高いので，被修飾語と同様に場面情報として扱う。またfrozen など動詞が変化し て修飾している場合も，行為を表すものとして場面の意味の分布に入れることにする．他の形 容詞や注釈語 (上記の $\mathrm{Am} .=$ 米語) などは全て省いている.

\section{3 シソーラスによる意味の定義}

意味解析を行なう場合に問題になることは意味の定義である．意味は構文情報などとは異な ク，一意に定義することが難しく，統一がとれていない。ここではよく用いられているシソー ラスによる意味の分類 (Yarowsky 1992) に従い, Roget の International Thesaurus の第五版 を用いた，図 1 に示すように，概念は全部で 1073 カテゴリにトップダウンに分類され，さら に各カテゴリは品詞ごとにより細かい項目に分類されている，buck には複数の概念があるが, そのうちの一つの概念を図 1 に例として示してある.それは「牡鹿」という意味を持ち，カテ ゴリ 311 の 'Animal, Insects' の中の項目 311.5 の 'hoofed animal' の中に分類されている. 単 語はその用法に従って分類されるため，多義語は複数のカテゴリや項目に含まれることになる. したがって，カテゴリや項目が特定されれば多義性が解消されたことにほほ等しくなる.

\subsection{Pictorial Dictionary とシソーラスによる場面情報}

OXFORD-DUDEN Pictorial English Dictionary (OPED) の各場面と Roget 5th ed. International Thesaurus(以下シソーラスとする) を組合せ, 場面情報を構築する，場面情報の表現 


\begin{tabular}{|c|c|}
\hline$\left[\begin{array}{l}1 \text { Birth } \\
22 \text { The Body } \\
\vdots\end{array}\right.$ & $\mid \begin{array}{l}311.1 \text { animal life,... } \\
-311.2 \text { animal, creature,... } \\
\vdots\end{array}$ \\
\hline $\begin{array}{c}-311 \text { Animals, } \\
\text { Insects } \\
\vdots\end{array}$ & $\begin{array}{c}311.5 \text { <hoofed animals }> \\
\text { deer, buck, doe,... } \\
\vdots\end{array}$ \\
\hline $\begin{array}{r}\text { L } 1073 \text { Space } \\
\text { Travel }\end{array}$ & L 311.60 marine animals ... \\
\hline カテゴリレベル & 項目レベル \\
\hline
\end{tabular}

図 1 Roget International Thesaurus の概要

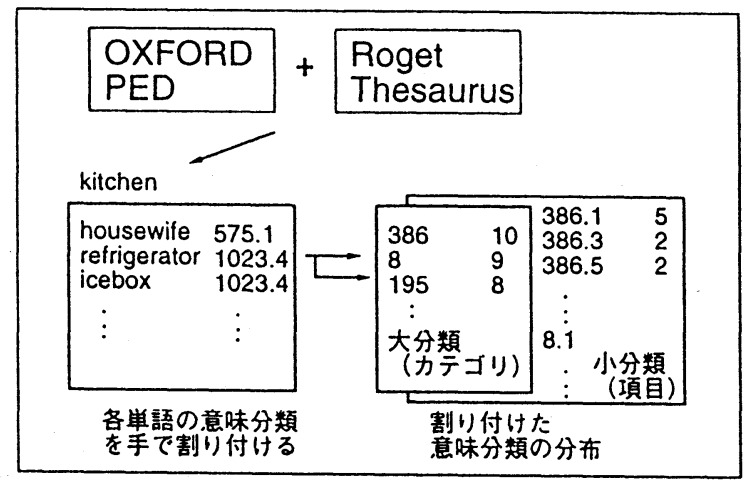

図 2 場面情報の構築

として (a) 出現単語とその意味をテーブルとして持つ方法と, (b) 場面に現れる意味分類の出現 頻度の分布として持つ方法とがある。(a) は OPED に出てくる単語に対応する意味を人間がシ ソーラスの最も細かい分類である項目レべルの分類の中から手で選び，その語の意味として登 録する (困 2 左下参照). (b) の意味分布は (a)の単語と意味の対のリストから作成される. (a) では各単語の意味の項目分類 (例えば buck の意味の一つは hoofed animal を示す 311.5) が単 語ごとに記録されているが，(b)ではこの単語ごとの枠を外し，場面全体で頻度をとる (困 2 右下参照). 例えば buck の他にも deer という単語などが狩猟の場面にあるが, これはやはり hoofed animal を表す 311.5 の意味を持つため, 311.5 の項目の頻度に加算される.この頻度リ ストを (b) の項目レベルの場面情報とする.さらにこの頻度リストをカテゴリ内で加算するこ とによって (b) のもう一つの場面情報であるカテゴリごとの頻度リストが得られる。これをカテ ゴリレベルの場面情報とする．例えば項目レベルのリストで hoofed animal を表す 311.5 が 5 , 
表 1 各場面での単語情報

\begin{tabular}{|l|l|l|l|}
\hline & 狩猟 & ルーレット & 台所 \\
\hline \hline 被修飾名詞 & $94 / 114$ & $42 / 52$ & $45 / 61$ \\
修飾名詞 & $41 / 44$ & $15 / 15$ & $29 / 33$ \\
動詞 & $20 / 21$ & $2 / 2$ & $6 / 7$ \\
\hline 合計 & $155 / 179$ & $59 / 69$ & $80 / 101$ \\
\hline
\end{tabular}

marine animal を表す 311.60 が 10 であった(他は 0 とする) 場合は，このカテゴリレベルでの 311 は頻度 15 になる。このように(b) に関しては, Thesaurus は図 1 のように, 項目レベル (例: 728.6) とより大きな分類であるカテゴリレべル (例: 728) があるので, 選択の余地がある.

ターゲットとする単語の多義性を解消する処理に際して, 場面として全ての単語が正しい頻 度情報で登録されている場合には，(a)のテーブルのみで十分なのだが，現実には出現する全て の対象物に関する情報を集めることは不可能に等しく，未登録の単語が必ず現れると思われる. その場合には (b) の意味分布を持つ方法によって場面情報の近似を行なう. ある程度十分な量 の単語が登録されていれば，(b)での項目レベルの意味を解答すれば良い近似になるが, 登録単 語が少ない場合にはカテゴリレベルまで拡げ補間をする必要がある。しかし逆に，単語どうし で意味の干涉が起こり, 近似が悪くなる可能性がある。例えば, 上の例では bucks の意味は正 確には 311.5 であるが，カテゴリレベルでは 311 という大きな分類の分布しか持たないので， このような細かい意味の選別はできなく，311 の下にある意味に関してはランダムに取り出す しかない. また実験の章で具体的に述べられるように，ルーレット(ギャンブル)の場面全体で は土台を表す 900 という分類の頻度が多い.このため, ルーレットの場面では bucks は本来は 「ドル (お金)」を示して欲しいところが、「鞍馬の台」を示してしまう結果になっている。この ように，意味の補間による未登録語への対処と，トレードオフの関係になっている。このため, 次章での実験の結果により有利な方を使用する.

視覚辞書 OPED に基づく場面中の単語を分類し, 統計をとった例を表 1 に示す。'/の右側 は単語の全数, 左側はシソーラスに単語が登録されている数を示している，場面の意味分布の 例として, 狩編の場面情報を表 2 に, ギャンブル (ルーレット) の場面情報を表 3 に，そして 台所の場面情報を表 4 に示す。ここでは大きい分類であるカテゴリレべルの分類を用いた。こ れを見ると各場面はシソーラスの様々な分類から構成されていることがわかり, 視覚的な場面 の情報量の多さがうかがえる。それぞれの頻度は OPED のその場面における単語の意味のう ち，そのカテゴリに属するものの数である. シソーラスは同じ物体を指すものであっても，観 点によって微妙に異なる分類をすることがあるので, 一単語が同じ物体を指しながら複数の力 テゴリに属する場合もある. そのため全体の頻度が表 1 の単語数よりも多くなっている. 例え ば, 表 1 の狩猟の場面での, シソーラスに登録されている単語数 155 よりも多い, 255 の意味 
表 2 狩猟の場面を構成するカテゴリの分布

\begin{tabular}{|c|l|l|l|r|}
\hline 順位 & カテゴリ & カテゴリ名 & 概念 & 頻度 \\
\hline \hline 1 & 382 & Pursuit & 追跡 & 42 \\
2 & 311 & Animals, Insects & 動物, 昆虫 & 41 \\
3 & 308 & Killing & 殺傷 & 11 \\
4 & 76 & Masculinity & 雄 & 8 \\
4 & 346 & Concealment & 隠蔽 & 8 \\
6 & 383 & Route, Path & 道 & 7 \\
7 & 8 & Eating & 食事 & 6 \\
7 & 159 & Location & 場所 & 6 \\
7 & 462 & Arms & 武器 & 6 \\
7 & 900 & Support & 支え (土台) & 6 \\
7 & 903 & Pushing,Throwing & 押し出し & 6 \\
- & その他のカテゴリ & - & - \\
\hline & total & & & 255 \\
\hline
\end{tabular}

表 3 ギャンブル (roulette) の場面を構成するカテゴリの分布

\begin{tabular}{|c|l|l|l|r|}
\hline 順位 & カテゴリ & カテゴリ名 & 概念 & 頻度 \\
\hline \hline 1 & 759 & Gambling & ギャンブル & 34 \\
2 & 244 & Quantity & 量 & 8 \\
3 & 743 & Amusement & 娛楽 & 6 \\
3 & 758 & Cardplaying & カードゲーム & 6 \\
5 & 900 & Support & 支え (土台) & 4 \\
5 & 914 & Rotation & 回転 & 4 \\
7 & 197 & Room & 区画 & 3 \\
7 & 280 & Circularity & 円形 & 3 \\
7 & 729 & Finance, Investment & 財政, 投資 & 3 \\
7 & 881 & Five and Over & 5 以上 & 3 \\
- & その他のカテゴリ & - & 27 \\
\hline & total & & & 101 \\
\hline
\end{tabular}

表 4 台所の場面を構成するカテゴリの分布

\begin{tabular}{|c|l|l|r|r|}
\hline 順位 & カテゴリ & カテゴリ名 & 概念 & 頻度 \\
\hline \hline 1 & 386 & Store, Supply & 保管, 供給 & 10 \\
2 & 8 & Eating & 食事 & 9 \\
3 & 195 & Container & 容器 & 8 \\
3 & 239 & Channel & 水路 (管) & 8 \\
5 & 11 & Cooking & 料理 & 7 \\
6 & 742 & Ceramics & 陶磁器 & 6 \\
7 & 79 & Cleanness & 清潔さ & 4 \\
7 & 293 & Closure & 閉銷 & 4 \\
7 & 1023 & Refrigeration & 冷却 & 4 \\
- & その他のカテゴリ & - & - & 55 \\
\hline & total & & & 115 \\
\hline
\end{tabular}




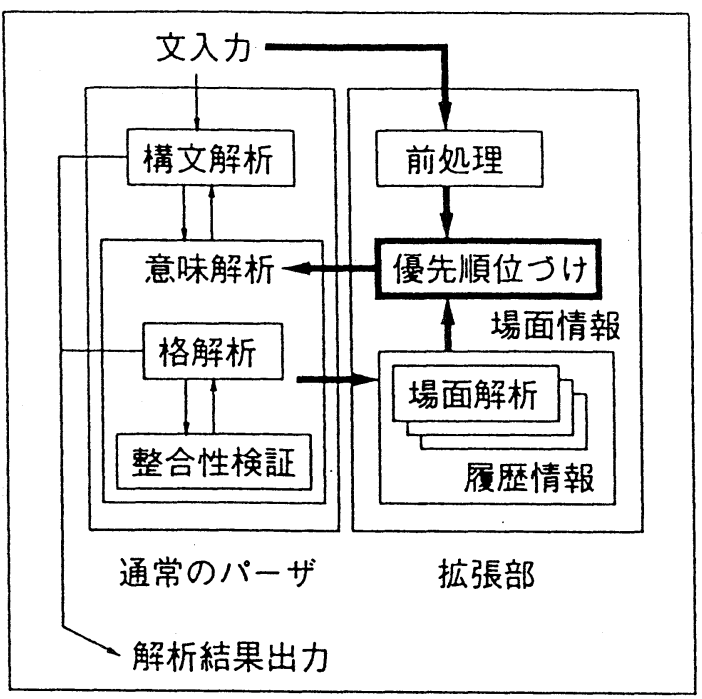

図 3 システムの全体構成

が表 2 に割り付けられている。

\section{3 文脈としての場面情報を利用した多義語の優先順位づけ}

\section{1 全体構成}

仮定するシステムの全体構成は図 3 に示される。パーザは通常の統語解析アルゴリズム (田 中 1989）を想定しており，それに場面情報を扱う部分を拡張する．拡張部では文が入力される と品詞解析などの前処理を行ない，それまでに得られている文からの場面情報を加えることによ ク，目標とする単語の各意味を優先順位づけする，その結果は統語解析アルゴリズムに渡されて 従来の手順に従って解析が進められる. 前処理での主な処理である品詞解析に際しては, 現在高 い正答率で解が得られる Hidden Markov Model によるモジュール (Cutting, Kupiec, Pedersen, and Sibun 1992) が存在するので，これを利用することを仮定する. 場面解析に関しては, 稿 を改めて述べることにする。ここでは場面および目標単語の品詞が一意に決まった場合を仮定 して議論を行なう。また形態素解析によって単語に切り分けた後の処理を行なうことにし, 特 に英語を対象として単語一つずつに対して処理が起動されることを想定している.

\section{2 優先順位づけの定式化}

場面が一つに決まった場合に，多義性解消の対象とする単語すなわち目標単語の候補とな る複数の意味の中から試行のために取り出す順番を決める順序列を求める. 予め場面に登録さ 
れていない単語の意味を推測すること，そして登録されている単語の意味をなるべく正確に保 存するために, 前述の (a) 予場面に出現する単語と対応する意味を対として持つテーブル, (b) 場面に現れる意味分類の出現頻度の分布，の大きく分けて二種類の情報を用いる．まず目標 単語が場面の (a)のテーブルに登録されてあるか調べ，登録されている場合はその意味を結果 として用いる，例えば， 'table'という単語には「机」や「表」など多くの意味がある。しかし OPEDの「台所」という場面に明示的に 'table'という単語が現れており，それは「机」(229 のカテゴリの中の 229.1 という項目で示される) という意味が割り付けられてあった. そこで システムはその意味を最初に出力する．この場合は「机」の尤もらしさを 1 とし，他の意味の 尤もらしさを 0 とする.

次に目標単語が場面の (a)のテーブルに登録されていない場合には (b) の意味分布を調へ， 目標単語の意味の候補リストの中で尤度の最も高いものから順番に取り出して意味解析部に渡 す. 例えば 'glass’という単語は OPEDの「台所」という場面には現れていない.しかしその 場面の全体の意味の傾向を利用して 'glass' の意味を推測したい. 例えばカテゴリレベルの場面 情報で考えてみると,「台所」という場面では「容器」を表す分類の尤度が 8 であり, 'glass'の いくつかの意味の中では最も高い值を持っている，そこで「容器」として「コップ」の意味を 優先して出力し,「鏡」などの意味は優先度を下げる.

この様子を定式化してみる. 目標単語を $W$ (例: glass), 単語の意味を $M$ (例: コップ), 文脈 を $C$ (談話全体), 場面を $S$ (例: 台所), 意味分類を $k$ (例: $1.1 \sim 1073.14)$, 目標単語の意味の正 解を $M_{c_{j}}$ (例: コップ, 鏡), そして対応する目標単語の意味分類の正解を $k_{c_{j}}\left(1 \leq j \leq n_{c}, n_{c}\right.$ は 正解の数) (例: 195.1(コップ), 29.6(鏡)) とする. また単語の意味と意味分類が 1 対 1 に対応す る場合を考えることを仮定する。

このとき文脈 $C$ の中で $W$ があったとき，その意味が $M$ である尤度 $L(W, C, M)$ を用いる と, 目標単語の意味 ( $n$ 個) の試行順序決定のための半順序列 $\mathrm{T}$ は以下のように書くことがで きる.

$$
\left\{M_{1}, M_{2}, \ldots M_{n} \in \mathbf{T}: L\left(W, C, M_{i}\right) \geq L\left(W, C, M_{i+1}\right)\right\}
$$

ただし $L\left(W, C, M_{i}\right)=L\left(W, C, M_{j}\right)$ となる部分はランダムに順番づけをする.

この場合には場面を一つに決定したときの目標単語の各意味分類の尤もらしさを利用するた

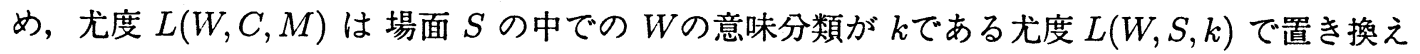
ることができる。

$$
L(W, C, M)=L(W, S, k)
$$

さらにこの尤度 $L(W, S, k)$ は本来は事前分布 (文脈情報なしの意味の分布) や条件付き確率 (文 脈情報による意味の分布の変化) により事後分布 $p(W, S, k)$ (文脈情報を得な後の Bayes 事後確 率) を求めて比較すべきところだが, 事前分布や条件付き確率をすべて求めることは非効率的で 
あり，まだ正確には得られていないという現状のため，ヒューリスティクスとして場面を固定 したときのその場面中の意味分類の頻度 $n(k, S)$ を使うことにする.

$$
L(W, S, k)=n(k, S)
$$

したがって (1) 式は

$$
\left\{k_{1}, k_{2}, \ldots k_{n} \in \mathbf{T}: n\left(k_{i}, S\right) \geq n\left(k_{i+1}, S\right)\right\}
$$

となる。この順番に従って本手法は語の意味を出力する.ただし $n\left(k_{i}, S\right)=n\left(k_{j}, S\right)$ となる部 分はランダムに順番づけをする.

\section{4 実験と評価}

前章の方法に従い順番に出力される語義の候補を評価する。文章中での各単語の意味を人間 が判断し，前述のシソーラスの分類に従って正解として用意しておく．人間は同じものを指し ているとしながらも, シソーラスはより細かな観点の違いから異なるものと分類していること があるが，ここでは人間が選んだものをすべて正解とみなす。この正解のどれかをシステムが 最初に出力するまでの語義の検索回数 (試行回数) の期待值と, システムが最初に出力する候補 (第一候補) に正解が含まれている確率，および第二候補までに(第一候補含む) 正解が含まれて いる確率によって評価を行なう，試行回数を調べることにより，全体の処理速度をおおまかに とらえることができる，また多義性解消率から，提案するシステムの出力の正答率がわかる.

\section{1 例題における実験}

まず 1. での例題 ‘John shot some bucks.'をとりあげる. Roget のシソーラスの索引に付与 されている各単語の細かい項目レベルでの意味に基づき実験を行なう。'shot'に対しては動詞 shoot の過去形で 20 種類の意味, 名詞で 26 種類の意味, 形容詞で 5 種類の意味がある.また 'bucks'に対しては動詞 buck の三人称で 3 種類の意味, 名詞の複数形で 8 種類の意味がある. 上述した意味分布の頻度を調べた結果を, 'shot'に対しては動詞のみを表 5 に, 'bucks'に対し ては名詞のみを表 6 に示す. 他は全て 0 であった. 表の‘/の左側は場面情報の修飾名詞・被修 飾名詞の寄与の合計, 右側は動詞による寄与である。すなわち, 例えば辞書の「狩猟」の場面に 現れるものの一つに 'rabbit hole'（兔の穴）があるが，これは 'rabit'という修飾名詞，'hole' という被修飾名詞から成り立っていると考える。また， 'aiming position' (狙い位置) という ものも「狩猟」の場面に現れる。これは 'aim'という行為（動詞）で修飾された 'position'と いう名詞と考えることができる。このように, 主に修飾名詞, 被修飾名詞, 動詞が存在するが, 場面情報として修飾名詞と被修飾名詞の両方の名詞だけを使ったときと, 動詞だけを使ったと きの，場面に現れる意味分類の出現頻度が表の‘’の左側と右側にそれぞれ示されている。“意 
表 5 各場面での shot の意味

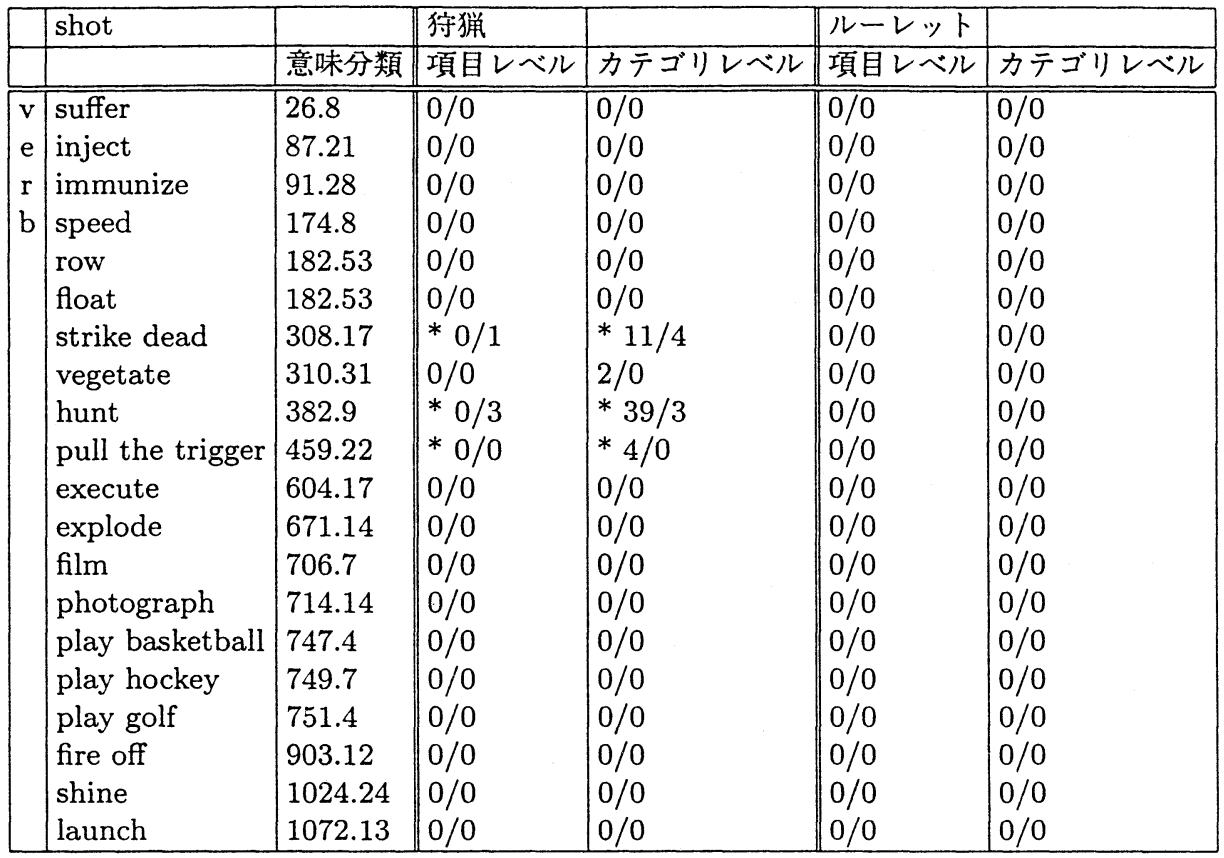

表 6 各場面での bucks の意味

\begin{tabular}{|l|l|l||l|l||l|l|}
\hline & bucks & & 狩猟 & & ルーレット & \\
\hline & & 意味分類 & 項目レベル & カテゴリレベル & 項目レベル & カテゴリレベル \\
\hline $\mathrm{n}$ & male animal & 76.8 & $* 8 / 0$ & $* 8 / 0$ & $0 / 0$ & $0 / 0$ \\
$\mathrm{o}$ & boy & 302.5 & $0 / 0$ & $0 / 0$ & $0 / 0$ & $0 / 0$ \\
$\mathrm{u}$ & hoofed animal & 311.5 & $* 5 / 0$ & $* 41 / 0$ & $0 / 0$ & $0 / 0$ \\
$\mathrm{n}$ & goat & 311.8 & $* 1 / 0$ & $* 41 / 0$ & $0 / 0$ & $0 / 0$ \\
& hare & 311.24 & $* 6 / 0$ & $* 41 / 0$ & $0 / 0$ & $0 / 0$ \\
& leap & 366.1 & $0 / 0$ & $0 / 0$ & $0 / 0$ & $0 / 0$ \\
& money & 728.7 & $0 / 0$ & $0 / 0$ & $* 0 / 0$ & $* 2 / 0$ \\
& trestle & 900.16 & $0 / 0$ & $6 / 0$ & $0 / 0$ & $4 / 0$ \\
\hline
\end{tabular}

味分類'はそれぞれの意味をシソーラスのラベルづけによって表現したときの番号を示し, 整数 部はカテゴリレベル，小数点以下の部分はより細かい項目レベルを表している．シソーラスで の項目レベル，カテゴリレベルの意味分類でそれぞれ場面情報を構成した場合の結果を表方。

場面情報の構成手順は，まず OPED の各場面に出てくる名詞と動詞に対してシソーラス中 から場面にふさわしい意味分類項目を付加する (テーブルレベルとする). 次に単語の枠を外し， 場面全体での各意味分類項目に対しての頻度を求め，これを項目レベルの場面の意味分布とす る (項目レベル). そしてさらに各カテゴリ内にある意味分類項目の頻度を足し合わせたものを， 
カテゴリレベルの場面の意味分布として使用する (カテゴリレベル).

表 5 に示した 'shot'の意味では, 項目レべルでは 'sem'の欄の各意味分類の頻度を場面情 報から取得した結果, ‘hunt(382.9)' という意味に対しての場面中の修飾名詞と被修飾名詞の寄 与は 0 , 動詞の寄与は 3 であることがわかる. カテゴリレベルは各意味分類項目 (例えば 382.9) を含むカテゴリ (382) 全体に対しての頻度が表されている. 表 5 , 表 6 の‘*' は人間がそれぞれ の場面で手で選んだ正解を示している.

狩猟とルーレットの各々の場面での 'shot'と 'bucks'のそれぞれの試行回数を求めた結果を 表 7 , 表 8 に示す．表の横方向は場面情報として用いた単語の品詞による分類を表す.「名詞の み」とは，辞書中の各場面に現れる名詞だけを情報として使ったときを示し「動詞のみ」とは 動詞だけを使ったとき，そして「名詞十動詞」は両方を場面情報として使った場合を示す。ま た‘’の左側は 'shot'の場合には動詞の中の意味分類から正解を選ぶまでの試行回数であり， 'bucks'の場合には名詞の中の意味分類から正解を選ぶまでの試行回数である. ‘の右側は全 品詞を区別しなかった場合の，全意味分類から正解を選ぶまでの試行回数である.

表 7 , 表 8 から得られることは,

（1）全品詞の中から正解の意味分類を得るまでの試行回数は，品詞を予め特定した場合に 比べると，正解が目標単語の意味リストにある場合にはほとんど増えないが，正解が 目標単語の意味リストにない場合には全ての意味リストを試す必要があるために，致 命的に試行回数が増えてしまう。(例: ルーレットでの 'shot')

（2）英語の動詞は名詞よりも隠喻的な要素が強く, 意味を特定することが難しいばかり か，意味リストにないことも多い. (例: ルーレットでの 'shot')

（3）場面情報に動詞の数が名詞ほど集まらなく，不安定である.

（4）表 7 , 表 8 の結果から考察すると, 場面情報には名詞と動詞は合わせて登録した方が 良い.

などであり，その結果実文における解析では

（1）品詞の特定はこの方法では扱わず，より信頼性の高いPart-Of-Speech(POS) Tagger(Cutting et al. 1992) などの利用を想定する. 特にこれは目標とする単語の品詞 を, 前後の単語との関係から Hidden Markov Model により求めるもので, Brown Corpus 1,000,000 語に対して $96 \%$ の正答率を持っているので, 前処理として有用で あると思われる。

（2）今回の実験では動詞の多義性は扱わない.

（3）場面情報は名詞と動詞を合わせて登録する。

という設定を設けることにした。 
表 7 各場面での shot の正解の意味までの試行回数

\begin{tabular}{|l|l|l|l|l|}
\hline & & 名詞のみ & 動詞のみ & 名詞十動詞 \\
\hline \hline 狩猟 & テーブル & $1 / 1$ & $1 / 1$ & $1 / 1$ \\
& 項目 & $5.23 / 7.77$ & $1 / 1$ & $1 / 1$ \\
& カテゴリ & $1 / 1$ & $1 / 1$ & $1 / 1$ \\
\hline ルーレット & テーブル & - & - & - \\
& 項目 & $21 / 31$ & $21 / 31$ & $21 / 31$ \\
& カテゴリ & $21 / 31$ & $21 / 31$ & $21 / 31$ \\
\hline
\end{tabular}

表 8 各場面での bucks の正解の意味までの試行回数

\begin{tabular}{|l|l|l|l|l|}
\hline & & 名詞のみ & 動詞のみ & 名詞+動詞 \\
\hline \hline 狩猟 & テーブル & $1 / 1$ & $1 / 1$ & $1 / 1$ \\
& 項目 & $1 / 1$ & $1.80 / 2.40$ & $1 / 1$ \\
& カテゴリ & $1 / 1$ & $1.80 / 2.40$ & $1 / 1$ \\
\hline \multirow{1}{*}{ ルーレット } & テーブル & - & - & - \\
& 項目 & $4.5 / 6$ & $4.5 / 6$ & $4.5 / 6$ \\
& カテゴリ & $2 / 2$ & $4.5 / 6$ & $2 / 2$ \\
\hline
\end{tabular}

\section{2 テキストにおける実験}

テキストに対する評価実験の対象として，モンゴメリー作の「赤毛のアン」の英語原作の中 から台所のシーンを切りだし，台所に登場すると思われる名詞を選定して上記の方法に従い評 価を行なった，場面情報によらない結果および台所の場面情報の登録語，未登録語の個数を表 9 に示す。

選定した名詞でシソーラスに登録されている名詞の多義性の度数分布，およびランダムに意 味分類を取り出した場合の, 正解までの試行回数の分布を図 4 に示す. 困 4 からわかるように, 多義性の度数は正解が得られるまで意味分類を取り出す回数の最悪の場合を表し，場面情報な しでランダムに取り出した場合の正解までの試行回数は正解が得られるまで意味分類を取り出 す回数の平均值を表す。

以下，各種条件で試行回数を求めた結果を示し，詳細な考察を次章で行なう.

台所の場面情報に登録されている名詞に対して，場面情報を使わずにランダムに取り出した 場合の試行回数の平均 ${ }^{1}$ と, テーブルレベルの場面情報を使った場合の試行回数の平均を表 10 に示す．平均值を見ることにより，単語による試行回数の度合や試行回数の減少の度合のばら つきを吸収し，全体の速度向上の様子をおおまかにとらえることができる．表 10 の結果から ランダムに意味を取り出すよりも，テーブル引きや項目レベルの場面情報を用いた処理を行な

1 比較のための場面情報なしの場合の取り出し順は, 語義の頻度に応じた順序づけに従うのが理想であるが, 今回用いた Roget のシソーラスにはその様な情報は考慮されておらず，登録順は各分類の出現順に従っているため，その順番に意 味があるとは判断せず, デフォルトの優先づけを想定せずにあらゆる場合の平均をとることにした。 
表 9 選定した名詞の基本情報

\begin{tabular}{|l|c|}
\hline 台所に関係する全名詞 & 357 個 \\
\hline シソーラスに登録されている名詞 & 341 個 \\
多義数の平均 & 4.13 個 \\
正解までの試行回数の期待値の平均 & 2.10 回 \\
(場面情報なし) & \\
\hline シソーラス情報に登録されている名詞のうち & \\
台所の場面情報に登録されている名詞 & 114 個 \\
シソーラス情報に登録されている名詞のうち & \\
台所の場面情報に登録されていない名詞 & 227 個 \\
\hline
\end{tabular}

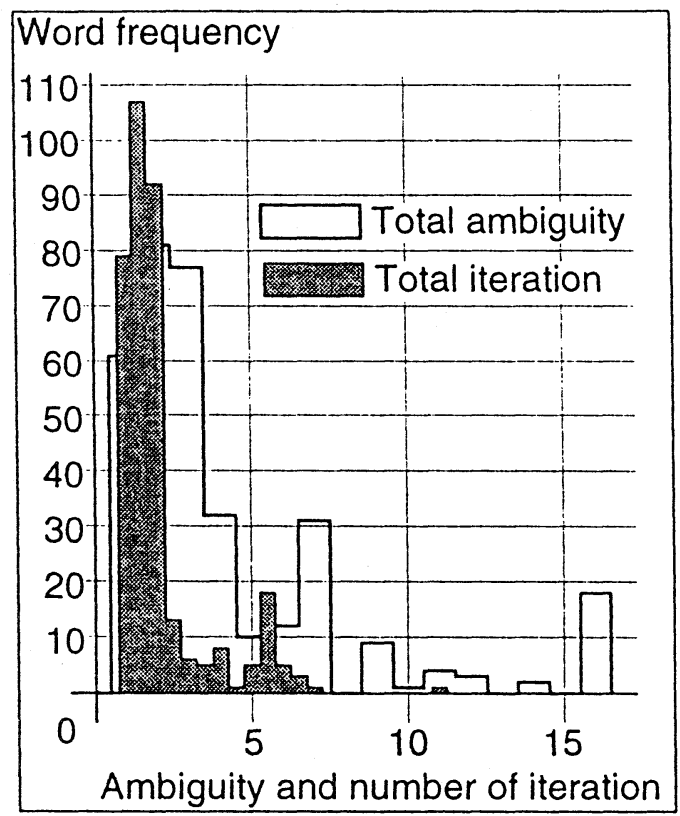

図 4 シソーラスに登録されている名詞の多義性の分布および正解までの試行回数の分布 (場面情報なし)

うと，平均して二倍以上速くなる.

またそれぞれの場合の分布を図 5 に示す。参考のために，項目レベル，カテゴリレベルの 場合での分布も示す. 各単語の正しい意味まで語義を検索する回数の期待値を，わかりやすく するために累積した結果のグラフが示されている．この結果ではテーブルレベルと項目レベル は值が同しであり，グラフが重なっている，以下のグラフで，台所の場面情報に登録されてい る名詞に関しては，テーブルレベルと項目レベルは全く同じ結果を示しグラフが重なっている. どの場合も 6 回の検索までに正解が得られている. 期待值 1 で正解が得られる単語の数の割合 は，場面情報なしのときの $22 \%$ に対し，テーブルレベルと項目レベルの場面情報で優先づけ 
表 10 台所の場面情報に登録されている名詞の試行回数の平均

\begin{tabular}{|l|l|}
\hline 方法 & 試行回数の平均 \\
\hline ランダム $($ 場面情報なし $)$ & 2.37 回 \\
テーブルレベル & 1.05 回 \\
\hline
\end{tabular}

表 11 台所の場面情報に登録されていない名詞の試行回数の平均

\begin{tabular}{|l|l|}
\hline 方法 & 試行回数の平均| \\
\hline ランダム(場面情報なし) & 1.96 回 \\
項目レベル & 1.86 回 \\
カテゴリレベル & 1.50 回 \\
\hline
\end{tabular}

した結果は $96.5 \%$ まで上昇する.

台所の場面情報に登録されていない名詞の試行回数の平均を表 11 に，分布を図 6 に示す. 対象は場面に登録されていない語なので，テーブルレベルに関する情報はない. 期待值 1 で正 解が得られる単語の数の割合は，場面情報なしのときの $24 \%$ に対し，カテゴリレベルの場面 情報で優先づけした結果は $73 \%$ まで上昇する。

以上の結果から，システムとしてはターゲットとする語が場面情報に登録されているかどう かをまず調べ，

・場面情報に登録されている名詞に対してはテーブル引きによる優先順位づけを行なう

・場面情報に登録されていない名詞に対してはカテゴリレベルによる場面の意味分布を用 いて優先順位づけを行なう

という方法をとることにし，その結果を表 12 に示す.

また第一候補解，第二候補解までの多義性解消率を表 13 ，またその分布を図 $7,8,9,10$ に 示す．各単語の意味を一つ取り出したときに，それが正解となる確率が求まる。ささらに単語の 出現頻度も考慮し，その確率の平均をとったものが多義性解消率である．場面情報の有無や種 類によって意味の取り出し方が異なる。その違いが表 13 に示されている．困 7 は場面に登録 されている名詞 113 語に対してシステムが最初に出力する意味が正解となる確率であり, 縦軸 は語数である，例えば，場面情報を使わないとき (ランダム)では, 最初の候補が $100 \%$ 正解 になる語は 25 語であるが, テーブルや項目レベルの場面情報を使えば, 109 語まで上昇する. 図 8 は場面に登録されていない名詞 228 語に対してシステムが最初に出力する意味が正解とな る確率である，場面情報を使わないとき(ランダム)では，最初の候補が $100 \%$ 正解になる語 は 54 語であるが，カテゴリレベルの場面情報を使えば，166 語まで上昇する．図 9 は場面に登 録されている名詞 113 語に対してシステムが 2 番目までに出力する意味の中に正解が含まれて いる確率である，場面情報を使わないとき(ランダム)では，最初の候補が $100 \%$ 正解になる 語は 33 語であるが, テーブルや項目レベルの場面情報を使えば， 109 語まで上昇する. 図 10 


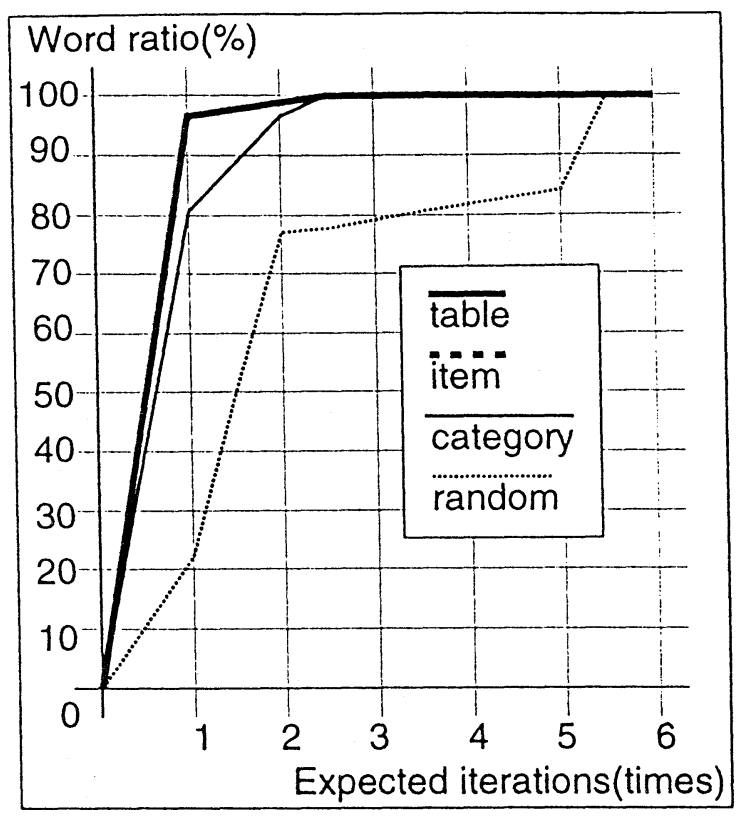

図 5 試行回数の期待値に対する選定名詞 (台所の場面情報に登録されている 113 語に対して)の割合の累積 (テーブル引き (table) と項目レベル (item) が重なっている)

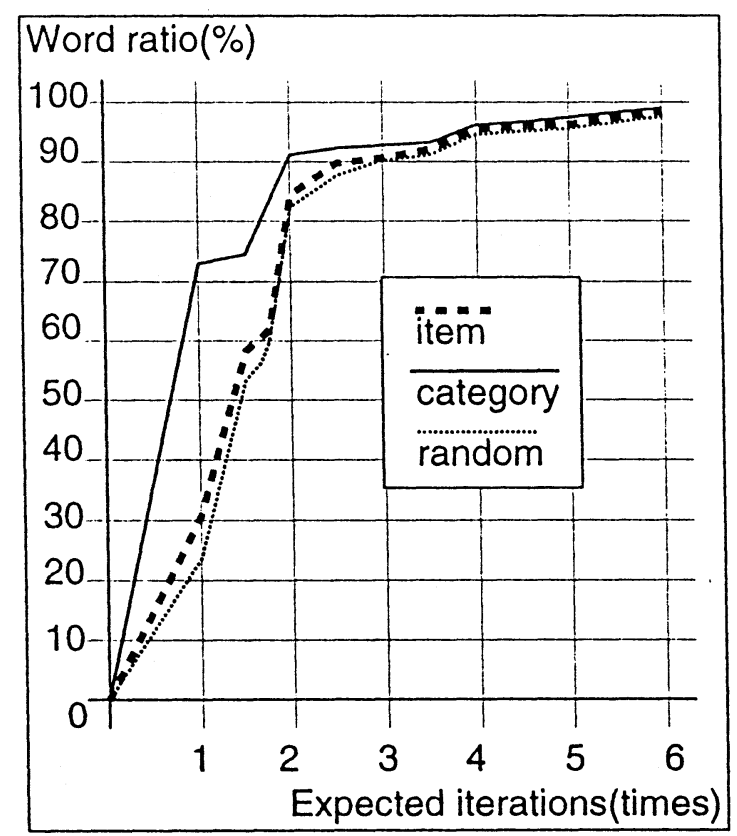

図 6 試行回数の期待值に対する選定名詞 (台所の場面情報に登録されていない228 語に対して)の割合の累積 
表 12 選定した全名詞への本手法の適用結果. 試行回数の期待値の平均による評価.

\begin{tabular}{|l|l|}
\hline 方法 & 試行回数の期待値の平均 \\
\hline ランダム (場面情報なし) & 2.10 回 \\
優先順位づけ後 & 1.35 回 \\
\hline
\end{tabular}

表 13 第一候補，第二候補までの多義性解消率 (\%)

\begin{tabular}{|l|l|l|l|l|}
\hline & ランダム(場面情報なし) & テーブル & 項目 & カテゴリ \\
\hline \hline 第一候補まで.登録名詞 & 51 & 96 & 96 & 81 \\
第一候補まで.未登録名詞 & 51 & 55 & 55 & 77 \\
\hline 第一候補まで.選定全名詞 & 51 & 69 & 69 & 78 \\
\hline 第二候補まで. 登録名詞 & 71 & 99 & 99 & 99 \\
第二候補まで. 未登録名詞 & 67 & 74 & 74 & 83 \\
\hline 第二候補まで. 選定全名詞 & 69 & 82 & 82 & 88 \\
\hline
\end{tabular}

表 14 選定した全名詞への本手法の適用結果. 第一候補解，第二候補解までの多義性解消率 (\%)による評価.

\begin{tabular}{|l|l|l|}
\hline 方法 & 第一候補 & 第二候補まで \\
\hline ランダム場面情報なし) & 51 & 69 \\
優先順位づけ後 & 83 & 88 \\
\hline
\end{tabular}

は場面に登録されていない名詞 228 語に対してシステムが 2 番目までに出力する意味の中に正 解が含まれている確率である，場面情報を使わないとき (ランダム) では，最初の候補が $100 \%$ 正解になる語は 121 語であるが，カテゴリレベルの場面情報を使えば，172 語まで上昇する.

表 14 に本手法の適用結果をまとめる，場面情報のテーブルに見つかった名詞に対しては テーブル引きによる優先づけを行ない，見つからなかった名詞に対してはカテゴリレベルによ る場面の意味分布を用いて優先づけをする.

\section{5 考察}

この章では場面情報を用いた場合に，ランダムに取り出した場合に比べて試行回数がうまく 減少しなかったとき，および場面情報のとり方による効果の差について考察を行なう.

場面情報に登録されている名詞に対してはテーブルレベルや項目レベルでの方がカテゴリレ ベルよりも試行回数が少なくてすんでいる。これに対して場面情報に登録されていない名詞で は項目レベルよりもカテゴリレベルの方が効果が大きい.このことは場面情報が不十分である ことを示す，場面情報に登録されていない語の意味を推定するために，場面情報に登録されて いた語の意味の分布を利用するのであるが，登録されていた語が少ない場合には，より上位の 分類であるカテゴリで分類を行なうことによって，情報の補間をする必要が生じている，例え 


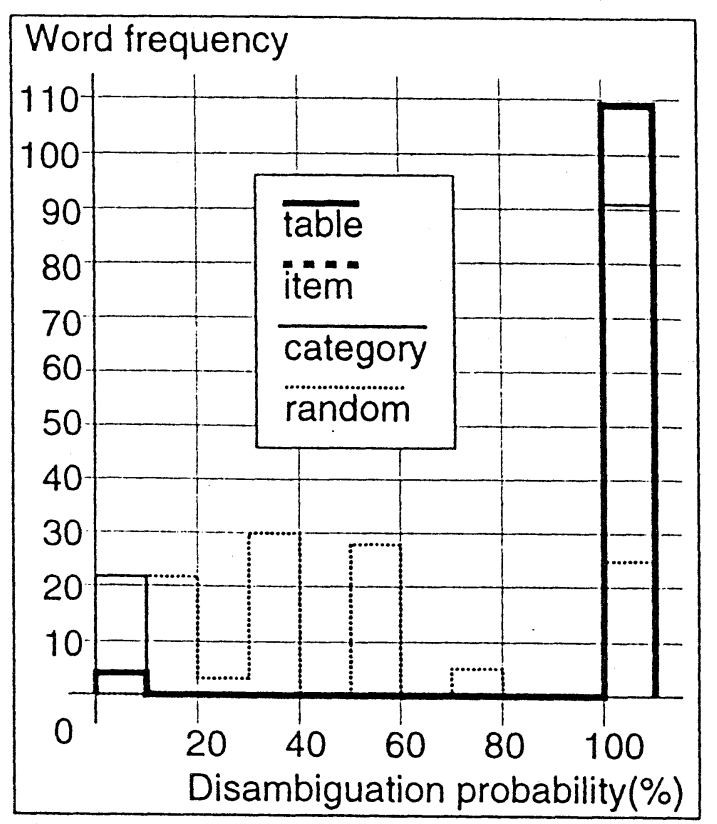

図 7 多義性解消率に対する語数 (登録されている 133 語の中で)

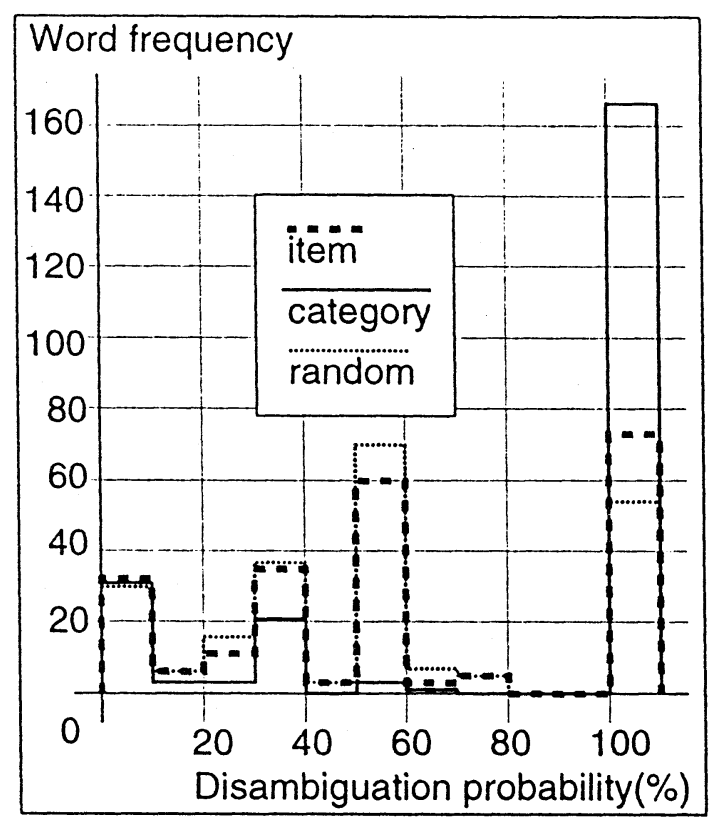

図 8 多義性解消率に対する語数 (登録されていない 228 語の中で) 


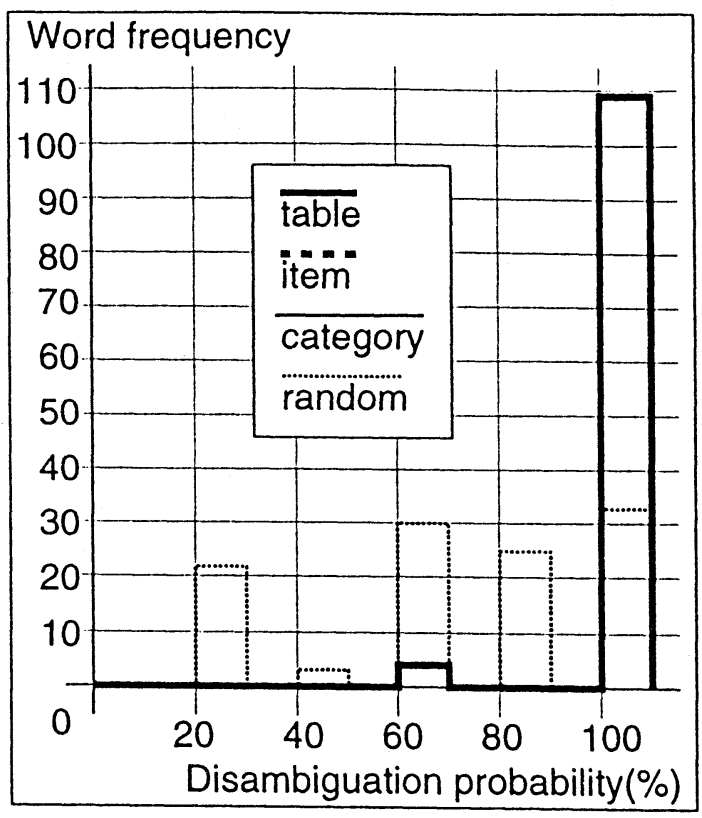

図 92 回の検索までに正解が得られる確率に対する語数 (登録されている 113 語の中で)

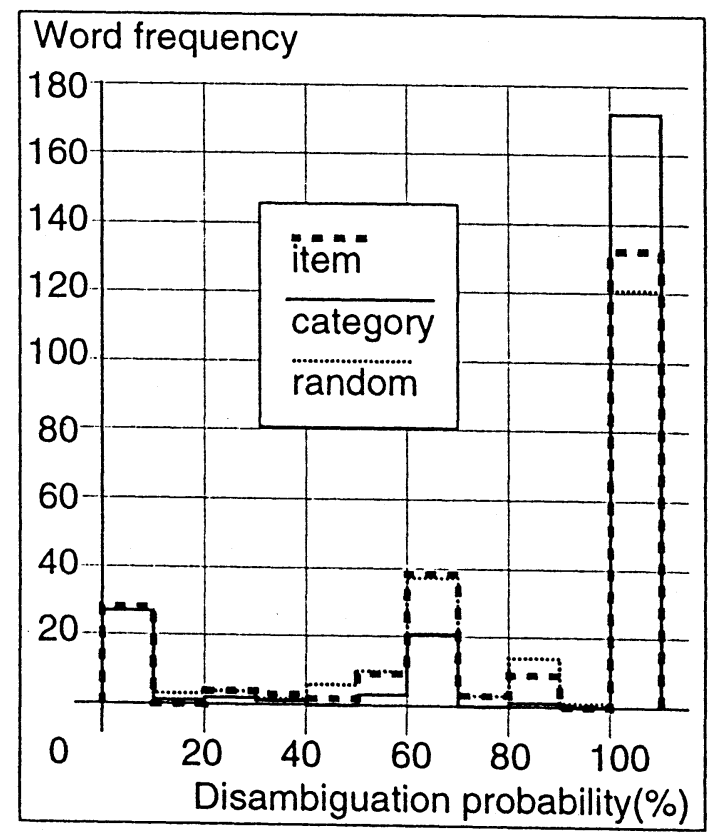

図 102 回の検索までに正解が得られる確率に対する語数 (登録されていない228 語の中で) 
ば登録されている名詞の細かい分類の方である項目レベルでの試行回数が登録されていない語 での場合に比べ少なくてすむことは，その名詞自身の意味が数えられていることが顕著に効果 を表していることを意味する。すなわちその語がたまたま場面情報に含まれていなかった場合 には，非常に不利になることから，場面を構成するために十分な意味の分布の統計量が得られ ていないと思われる。また十分な統計量が得られた理想的な場合では，登録されていない名詞 に関しても，ここでの登録されている名詞の項目レベル程度の少なさの試行回数が得られると 予想される。だがそのような理想的状態がいつも得られるとは限らなく，不完全な場面情報し か得られない場合には，今回の解析の結果のように，シソーラスのより上位のカテゴリレベル での補間が効果を持つものと思われる。

テーブル引きから項目レベルへ，また項目レベルからカテゴリレベルへというようにシソー ラスのより上位レベルを利用する際に問題となる点は補間による意味の干涉である。例えば, 'cream' はこの物語ではケーキに塗るための「ソフトクリーム」を表す．ところが, OPED で の場面全体の情報では「清潔さ」というカテゴリの頻度が多い。このためにカテゴリレべルで の情報を利用すると, ‘cream'の「洗剤」という意味の頻度が多くなってしまって正解が得られ なくなってしまっている.

また今回の文章での解析では現れなかったが, 同じ単語の形をとるが互いに意味が異なる複 数の物が一つの場面に同時に現れる場合があり，この場合はテーブル引きをしても効果が減少 する，例えば今回用いた台所の場面情報の中に'plate'という単語が $2 つ$ 含まれているが，1つ は「皿」の意味であり，もう1つは「ホットプレート」の天板の意味であった，ただしそのよ うな事例が出現する確率は非常に小さいものと思われる.

場面情報なしの場合に比べて悪くなってしまう例は‘door', 'biscuit', 'snap'である. 'door' の人間が判断した意味はシソーラスの項目 189.5, 189.6 の「入」であるが, システムが最初 に提示した解は 292.6 の「開放」という抽象的概念であった. 'biscuit'は 10.29, 10.41 の「食 べ物」が正解なのであるが, 742.2 の「セラミクス(チップ)」を提示している．これは台所の場 面には「陶磁器」が多いためである. 'snap' は8.2の「クッキー」が正解であるが, 68.2 の「ピ リッとすること」を提示している。これは場面中の「こしょう」による影響と思われる。この ような場合に対処するには, なるべく多くの単語とその意味を対にして持つことが重要である.

\section{6 今後の課題}

今回の実験では場面を一つに固定した場合の名詞の多義性に対して優先順位づけの効果を明 らかにしたが，場面を決定する機構は課題として残されている．場面を決定するためには

- 談話中の場面構造の切り出し

- 切り出した場面の特定

・ 新たな場面情報の学習 
を明確にする必要がある．場面は今回想定したようにそれぞれの文章に対して一つずつ決まる 場合の他にも，入れ子などの構造を持つことがある．例えば会話文中や回想などでの場面と話 者のいる場面の関係などがあげられる，各文章に対する場面が一つに決まる場合には，場面の 切りかえを検出する必要があり, 入れ子構造などを持つ場合にはさらに, 場面と場面の関係も 自動的に検出する必要がある．場面構造を切り出すためには焦点の解析や照応問題の解決が必 要になる (角田・田中 1994). そして切り出した場面に対して場所名が明示的に与えられない場 合には最尤の場面を推定する必要がある (Tsunoda and Tanaka 1994)。また場面の特定と文の 理解は一方向でないことも考虑に入れる必要がある．場合によっては，場面の特定によって文 が理解できた後でも，矛盾が生じて場面が変わりうる場合もあるし，より詳細な場面情報を提 供する場合もある，テキスト全体からおおまかに場面を切り出し，その後で文ごとの詳細な格 解析を行なった結果から，本当にその場面の同定が正しかったかを検証し直すことが一つの方 法である。

今回は視覚辞書である OXFORD-DUDEN Pictorial English Dictionary を場面情報として 用いたが，このような辞書の情報が現実の世界の近似を十分に行なっていない場合には，場面 内の対象物を新たに学習する方法，また新たな場面を獲得する方法が必要になるが，それは将 来画像処理や画像認識との統合時の実現課題の一つであると思われる.

ここでは場面に基づく空間的な連想を文脈情報の一つとして扱ったが，動詞が状態変化をひ き起こす作用を分類した概念の辞書などの知識を用いたり, 視点の移動などを含めた談話構造 の解析を行ったりすることにより，時間発展などの他の連想関係を用いること，また動詞一名詞 などの共起関係を用いることを組み合わせた場合の制御方法などの検討を要すると思われる. 特に単語の意味間の直接の依存関係の整合性の問題があるが，これは格解析の結果の検証を行 ない，局所的な矛盾を起こさない解が得られるまですべての解析を繰り返す必要がある．また 今回は多義語の意味の分類に際してシソーラスを用いたが，意味の定義方法の問題は依然とし て残されており, 検討を要する。

\section{7 むすび}

英語名詞の多義性解消の効率化の問題に対し，空間的連想を用いた文脈情報として場面が寒 文に対し有意な結果を与えることを示した．視覚的情報に基づく辞書とシソーラスを組み合わ せる場合の構成方法の比較を行ない，考察を行なった，例として台所という場面に固定した場 合に登場する名詞に対しての評価の結果, 2.1 回から 1.35 回へ $56 \%$ の平均試行回数の速度向 上が見られている．多義性解消率は第一候補のみでは $51 \%$ から $83 \%$ に，第二候補まで出力 した場合には $69 \%$ から $88 \%$ に上昇する．共起関係などの情報をさらに利用することにより， 曖昧性の組合せ爆発を抑える有効な手段の一つと位置付けられる．今後は場面の切りかえ，同 定，学習などを含む場面の決定機構の構築の研究を行なう予定である。 


\section{謝辞}

匿名で本論文を査読してくださった方には大変適切で有用な助言を頂きました，大変感謝致 します。またこの研究の一部は文部省科学研究費の助成によります。

\section{参考文献}

Cutting, D., Kupiec, J., Pedersen, J., and Sibun, P. (1992). "A Practical Part-Of-Speech Tagger." In Third Conference on Applied Natural Language Processing. ACL.

Hirst, G. (1988). "Resolving Lexical Ambiguity Computational with Spreading Activation and Polaroid Words." In Small, S. e. a. (Ed.), Lexical Ambiguity Resolution. Morgan Kaufmann, San Meteo, California.

Rumelhart, D. (1975). "Notes on a Schema for Stories." In D.Bobrow and A.Collins (Eds.), Representation and Understanding. Academic Press.

Schank, R. C. (1982). Dynamic memory. Cambridge University Press.

Schank, R. C. and Abelson, R. P. (1977). Scripts, Plans, Goals and Understading. LEA.

Schank, R. C. and Riesbeck, C. K. (1981). Inside Computer Understanding. LEA. (石崎 俊 訳, 自然言語理解入門. 総研出版).

Tsunoda, T. and Tanaka, H. (1993). "Semantic Ambiguity Resolution by Parallel Distributed Associative Inference and Contradiction Detection." In Proceedings of IJCNN, Nagoya93, vol.1, pp. 163-166.

Tsunoda, T. and Tanaka, H. (1994). "Analysis of Scene Identification Ability of Associative Memory with Pictorial Dictionary." In Proceedings of COLING-94, Vol. 1, pp. 310-316. Waltz, D. L. and Pollack, L. B. (1985). "Massively Parallel Parsing: A Strongly Interactive Model of Natural Language Interpretation." Cognitive Science, 9 (1), 51-74.

Yarowsky, D. (1992). "Word-Sense Disambiguation Using Statistical Models of Roget's Categories Trained on Large Corpora." In COLING-92, pp. 454-460.

T.コホネン (1993). 自己組織化と連想記憶 (中谷 和夫 監訳). シュプリンガー・フェアラーグ 東京.

奥村学, 田中穂積 (1989). “自然言語解析における意味的暧昧性を増進的に解消する計算モテ” ル.”人工知能学会誌, $4(6), 687-694$.

片桐恭弘 (1989). “文脈理解一文脈理解のモデル.”情報処理学会誌, 30 (10), 1199-1206.

小嶋秀樹, 古郡延治 (1991). “テキスト解釈の曖昧性を知識と文脈によって解消する計算モデ ル.”情報処理学会論文誌, 32 (11), 1366-1373.

田村淳, 安西祐一郎 (1987). “Connectionist Model を用いた自然言語処理システム.”情報処理 学会論文誌, 28 (2), 202-210. 
角田達彦，田中英彦 (1994). “結束構造および一貫性に基づく場面構造の解析.”情報処理学会

第 49 回全国大会, 3 巻, pp. 121-122.

田中穂積 (1989). 自然言語解析の基礎. 産業図書.

\section{略歴}

角田 達彦: 1967 年生. 1989 年東京大学理学部物理学科卒業. 1995 年東京大学 工学系大学院博士課程修了. 工学博士. 同年京都大学工学研究科助手現在に 至る. IJCNN'93 Student Award 受賞. 1994 年情報処理学会学術奖励賞受 賞. 自然言語処理の知識と推論について研究中. 脳機能の数理化に興味を持 つ. 情報処理学会, 日本神経回路学会, 電子情報通信学会, 人工知能学会, 日本認知科学会各会員.

田中 英彦: 1943 年生. 1965 年東京大学工学部電子工学科卒業. 1970 年同大 学院博士課程終了. 工学博士. 同年東京大学工学部講師. 1971 年助教授, 1978 年 1979 年ニューヨーク市立大学客員教授，1987 年教授現在に至る. 計算機アーキテクチャ, 並列処理, 計算モデル, 帰納推論, 自然言語処理, 分散処理, CAD 等に興味を持っている. New Generation Computing 編集 長, 情報処理学会, 電子情報通信学会, 人工知能学会, ソフトウエア科学会, IEEE, ACM, 各会員.

(1994 年 10 月 21 日 受付)

(1995 年 3 月 23 日 再受付)

(1995 年 5 月 31 日再々受付)

(1995 年 9 月 8 日採録) 